\title{
Governance of the Sponge City Programme in China with Wuhan as a case study
}

\author{
Liping Dai, Helena F. M. W. van Rijswick, Peter P. J. Driessen \& Andrea M. \\ Keessen
}

To cite this article: Liping Dai, Helena F. M. W. van Rijswick, Peter P. J. Driessen \& Andrea M. Keessen (2018) Governance of the Sponge City Programme in China with Wuhan as a case study, International Journal of Water Resources Development, 34:4, 578-596, DOI: 10.1080/07900627.2017.1373637

To link to this article: https://doi.org/10.1080/07900627.2017.1373637
(2) 2017 The Author(s). Published by Informa UK Limited, trading as Taylor \& Francis Group

Published online: 13 Sep 2017.

Submit your article to this journal $\pi$

\section{Џlll Article views: 4047}

View Crossmark data $₫$

Citing articles: 4 View citing articles $₫$ 


\title{
Governance of the Sponge City Programme in China with Wuhan as a case study
}

\author{
Liping Dai ${ }^{\mathrm{a}, \mathrm{b}}$, Helena F. M. W. van Rijswick ${ }^{\mathrm{b}}$, Peter P. J. Driessen ${ }^{\mathrm{c}}$ and \\ Andrea M. Keessen ${ }^{b}$
}

aSchool of Law, Hubei University of Economics, Wuhan, China; ${ }^{b}$ Faculty of Law, Utrecht Centre for Water, Oceans and Sustainability Law, Economics and Governance, Utrecht University, the Netherlands; 'Faculty of Geosciences, Copernicus Institute of Sustainable Development, Utrecht University, the Netherlands

\begin{abstract}
In 2015, China's national government initiated a Sponge City Programme to address its urban flood issues. A sponge city is a city built around the concept of managing water in an ecologically sustainable way. The intention is to improve urban resilience through rainwater capture, storage and use. This article applies a four-mode governance framework to analyze the programme. It identifies the strengths and weaknesses of the programme implementation and provides recommendations.
\end{abstract}

\section{ARTICLE HISTORY}

Received 25 December 2016 Accepted 23 August 2017

\section{KEYWORDS}

Governance; Sponge City Programme; urban flooding; China; adaptation; climate change

\section{Introduction}

The twenty-first century not only marks the era in which more than half of Asia's population now lives in cities; it is also an age of the increasing frequency and intensity of environmental disasters. Urban flooding is foremost among disaster trends and directly impacts the lives and livelihoods of much of Asia's population (Miller \& Douglass, 2015). China has a long history of a serious losses of life and damage to property due to flooding, costing on average $1 \%$ of the annual gross domestic product (Kobayashi \& Porter, 2012).

The scientific community generally agrees that climate change will cause greater extreme weather, with more severe droughts; more intermittent, but more intense storms; and higher coastal storm surges (Kobayashi \& Porter, 2012). Many studies have demonstrated that regional and seasonal rainfall in China has changed and the urban flood risk has risen over the past decades (Duan et al., 2016; Piao et al., 2010). Cities are relatively vulnerable to surface water flooding due to the increase in artificial surfaces and decrease in green space, preventing excessive rainfall from entering the ground (Mees, 2014). Statistical analysis shows that up to $62 \%$ of the 351 cities investigated in China suffered severe floods between 2008 and 2010, and 137 of them were hit more than three times (Duan et al., 2016). The situation is only expected to worsen (Shepard, 2016).

Reflecting the challenges ahead, there is an urgent need to apply new approaches for sustainable urban water management. Against this backdrop, in April 2015 the Chinese 
government initiated a Sponge City Programme (SCP), aimed at addressing urban flooding and waterlogging (Ministry of Finance, Ministry of Housing \& Urban Development, \& Ministry of Water Resources, 2015). A so-called sponge city is built around managing water in an ecologically sustainable way, allowing water to permeate, to flow into runoff capture systems, and to be collected and reused. The central government has pledged to provide billions of dollars to help 30 selected cities facilitate their sponge projects over two three-year periods. The central government expects the programme to be scaled up nationwide and ultimately to help improve urban conditions.

\section{Aim and approach}

This article introduces and analyzes how the SCP is governed in China, and provides recommendations to improve this to facilitate the exchange of experiences with other cities facing similar problems in China and elsewhere. It discusses the strengths and weaknesses of the programme, the governance modes and the progress with which the Chinese national and local governments are rolling out the SCP.

\section{Analytical framework}

Adapting cities to the risks of 'too much' water over the coming years is not only a technical matter but also a governance issue (OECD, 2016). This article applies a governance framework, comprising four governance modes (Kern \& Alber, 2009), as a tool to analyze the governance of the SCP in China and Wuhan City.

Governing by example (Bulkeley \& Broto, 2012) is the capacity of a government to provide good practices, such as by taking measures concerning its own property. This term is used instead of self-governance (Kern \& Alber, 2009) because the latter term is frequently used to describe the motivation of market actors (Driessen, Dieperink, Laerhoven, Runhaar, \& Vermeulen, 2012).

Governing by authority is the use of traditional forms of authority such as regulations and sanctions.

Governing by provision is when practice is shaped through the delivery of services and resources, such as technical toolkits provided by different authorities.

Governing through (co)funding is supporting initiatives by private actors through partnerships.

No strict lines can be drawn between these four modes (Bulkeley \& Broto, 2012; Kern \& Alber, 2009), but they serve as heuristic tools for analyzing the SCP and its contribution to sustainable urban water management. In practice, more than one mode can be used in a governance arrangement.

This article investigates SCP governance at the national level and in a pilot city, Wuhan. After exploring the background and rationale of the SCP, its governance at national and city levels is investigated and compared, and the relationship between the two levels of governance is further analyzed. A discussion and conclusion then follow.

\section{Methods}

This article applies traditional desk research methods, analyzing primary sources (political speeches, public policies and regulations) and secondary sources (academic and media 
discussion) through the four governance modes. Political speeches are included as part of primary sources because of their influence on policies and governance in China. The desk research has been combined with interviews with people of diverse roles, such as government officials, policy makers, designers, academics, people from third parties and a project manager. Information was also gained from a two-day international symposium organized by an SCP design institute (CITIC General Institute of Architectural Design and Research) in Wuhan (SCP Symposium, 2016), and two workshops organized by the Wuhan Municipal Construction Commission and by the Wuhan Water Affairs Bureau.

Wuhan City was chosen as a case study because it is a pilot city of the SCP and it is vulnerable to flooding, being hit by flooding or waterlogging (stagnation of water on top of the soil surface) almost once every three years in the past few decades (China Urban Centre, 2016).

\section{Key challenges of urban water management: increasing climate risks}

China is prone to natural disasters. It is one of the five countries that were the most frequently hit by natural disasters from 2004 to 2014 (Guha-Sapir, Hoyois, \& Below, 2015), floods, landslides and storms being the most frequent. Statistics indicate that 26 out of 31 provincial-level mainland administrative regions (more than 1000 counties) suffered from flooding and waterlogging in the first half of 2016 alone, which, together with the associated disasters, killed 367 people and caused a direct economic loss of RMB 45.5 billion (USD 6.9 billion) (Ministry of Civil Affairs, 2016).

Climate change, urbanization and inappropriate drainage infrastructure are causes of urban floods. Climate change is increasing flood risks in China. More frequent extreme rainfall events were witnessed in recent years, particularly rainfall events of high intensity but short duration (Ding et al., 2007). A recent study provides evidence that the number of days of heavy precipitation has increased significantly and the number of consecutive dry days has decreased ( $\mathrm{Li}, 2013)$. The trend of increasing rainfall intensity is predicted to continue (Yin, Ye, Yin, \& Xu, 2015). This poses great challenges to urban drainage systems.

China has been experiencing rapid urbanization since the 1980s. The percentage of the population living in urban areas increased from 21\% in 1982 to 53\% in 2012 (National New Urbanization Plan (2014-2020), 2014). More than 40,000 square kilometres were newly urbanized in the country over the past 35 years, as the number of cities rose from 193 to 653 (Shepard, 2016). The dominance of impermeable surfaces makes cities less able to absorb large amounts of rainwater in a short time, which easily triggers floods.

Urban flooding and waterlogging in China are also triggered by poor drainage infrastructure, which has failed to keep pace with the expanding development above the surface. Half of China's cities have not met national flood-prevention safety standards (Shepard, 2016). Around $80 \%$ of the 640 cities have drainage systems designed with an average recurrence interval (a one-in- $X$-year chance of flooding) of less than 50 years (Huang \& Xu, 2006). Stormwater drainage capacity is far too small in most cities.

\section{Towards green urban policies: the introduction of the Sponge City Programme}

Green development has been central to China's national development plan for a decade. Its official development strategy to move towards a green economy is called Ecological 
Civilization. This concept was introduced by the National Congress in 2007 and became one of the national development strategies. It was listed along with economic, political, cultural and social progress as one of the five goals in the country's overall development plan at the 18th National Congress of the Communist Party in 2012 (China Daily, 2017). The essence of striving towards an Ecological Civilization is to build a resource-saving and environment-friendly society, as the former Chinese president stated (18th Party Congress Report, 2012).

Since 2007, initiatives and actions on climate change have become a noticeable trend in China. In June 2007, the central government announced the creation of a National Leading Group on Climate Change and issued a National Climate Plan. It outlines the country's strategy for addressing climate change through national programmes aimed at mitigation, adaptation, science and technology research, and increasing public awareness (National Development \& Reform Commission, 2015). Since then, China has taken many steps. For example, it became the world's biggest investor in renewable energy in 2014 (Sudworth, 2015). Together with many other countries, it ratified the Paris Climate Change Agreement in 2016 (Wernick, 2016).

The central government has introduced a range of green programmes nationwide. Green projects such as the Low Carbon City, the Water Conservation City, and the Smart City are being or have been initiated. Special chapters of a National New Urbanization Plan emphasize green city planning and development (National New Urbanization Plan (2014-2020), 2014)). The 13th Five-Year Plan (2016-2020) further highlights the use of rainwater and the construction of flood-control facilities, setting out a 'green is gold' top-level policy path to support the country's transition to an Ecological Civilization (CCICED, 2016).

The SCP is intended to use the full potential of rainwater to improve urban resilience. It aims to 'minimize the influence of urban development on the ecological environment by taking comprehensive measures for the improvement of water permeation, water retention, water storage, water purification, water drainage, water saving and water reuse' (State Council, 2015b). To date the SCP has been implemented at the national level in two batches. Sixteen cities were selected as pilot cities in the first batch in 2015, and 14 more were added in the second batch in 2016. The central government provides different amounts of start-up funding for these pilot cities, which are discussed in the following sections.

\section{Case study: Wuhan City}

Before turning to our case study, it is necessary to explain the interactions between the central and local governments in China. China is a unitary country: its political system is organized according to a hierarchy where local governments are supposed to implement decisions made by the central government (Ye Qi, Li Ma, Huanbo Zhang, \& Huimin Li, 2008). Any change in local governments' priorities is usually a result of requirements instituted or incentives offered by the central government, whether by formal legislation, political speeches, or policy documents (Dai, 2014; Ye Qi et al., 2008). The same conditions apply to the SCP: it is initiated and evaluated by the central government and implemented at the local level.

Wuhan is the capital city of Hubei Province in Central China and has a population of just under 8.5 million. The city occupies 8500 square kilometres, most of which is flatlands, with some hills and many lakes and pools. It enjoys a reputation as the River Town and the City 
of Hundreds of Lakes. The abundant water resources have created many development opportunities for Wuhan, but have also brought many problems, such as waterlogging and water pollution from urbanization and economic activities. Wuhan is located on a floodplain (Jianghan Plain), where the Yangtze River and the Han River intersect. The expansion of the city and the expected effects of climate change are increasing flood risks in the city. For example, a storm in the summer of 2016 caused serious urban flooding and killed more than 30 people. The weather trend shows a significant increase in precipitation for Wuhan due to climate change (Asian Development Bank, 2013).

Water pollution is a considerable issue in Wuhan. In 2014, four out of eleven rivers did not meet prescribed water quality standards. For historical reasons, these river areas were designed as 'discharge control areas' (areas with intensified drain outlets), from which partially treated industrial and domestic sewage were discharged into the Yangtze and Han Rivers. Besides point sources, diffuse sources of pollution are also a serious problem, because the district invests heavily in agriculture, where many pesticides and fertilizers are used (Dai, 2015).

In the light of existing flooding and pollution pressures, the Wuhan government gave priority to addressing the issue of waterlogging and supplemented this with water pollution control and rainwater collection and reuse through the SCP. In total 455 sponge projects were planned in two demonstration areas of the city, Qingshan and Sixin Districts, which cover 38.5 square kilometres (Table 1 ).

\section{Governance of the Sponge City Programme at the national level and in Wuhan City}

This section introduces and analyses, using the four-mode governance framework, the different modes of governance at the central and local/city levels and the mix of policy instruments used to develop and implement the SCP.

\section{Governing by example}

The sponge city urban design ideas had been experimentally used for some time before the SCP was formally initiated. For example, a Stormwater Park was created in the new urban district in Haerbin (Arch daily, 2013), and concrete water floodwalls were replaced by resilient river embankments in Jinhua (Turenscape Landscape Architecture, 2015). They have both

Table 1. Types, numbers and planned investments of sponge projects in Wuhan (2015-2017).

\begin{tabular}{|c|c|c|c|c|}
\hline Location & Size $\left(\mathrm{km}^{2}\right)$ & Projects & Number & Investment (millions) \\
\hline \multirow[t]{5}{*}{ Qingshan District } & 23 & City roads & 41 & RMB 2170 (USD 314.8) \\
\hline & & Public facilities in residential areas & 260 & RMB 1990 (USD 288.7) \\
\hline & & Parks and green areas & 12 & RMB 640 (USD 92.9) \\
\hline & & Urban river system & 5 & RMB 7000 (USD 1015.5) \\
\hline & & Urban drainage trench & 12 & RMB 1300 (USD 188.6) \\
\hline \multirow[t]{4}{*}{ Sixin District } & 15.5 & City roads & 38 & RMB 320 (USD 46.4) \\
\hline & & Public facilities in residential areas & 73 & RMB 790 (USD 10.6) \\
\hline & & Parks and green areas & 6 & RMB 210 (USD 30.5) \\
\hline & & Urban river system & 8 & RMB 1560 (USD 226.3) \\
\hline Total & 38.5 & & 455 & RMB 15,980 (USD 2214.3) \\
\hline
\end{tabular}

Source: Wuhan Water Affairs Bureau (2016). Guidlines of Sponge City Plan and Design, https://www.whwater.gov.cn/water/u/ cms/www/201507/08110535klk6.pdf 
been included as good examples of green sponges in China. Such good examples can help peer municipalities explore their potential for sustainable development. Indeed, when the SCP was officially initiated, the central government provided seven completed projects as showcases in its guidelines. The scope ranged from municipal roads and green roofs in new urban districts in South China (Guangzhou), to a rainwater collection system in an Expo Park in East China (Shanghai), to a residential district in North China (Beijing), and road greenbelts in a development zone in West China (Urumqi) (Ministry of Finance, Ministry of Housing \& Urban Development, \& Ministry of Water Resources, 2015).

In Wuhan, a Garden Expo Park, built between 2012 and 2015, is now promoted as a good example of a sponge project. The park covers an area of around $30 \mathrm{~km}^{2}$. It was built on the biggest rubbish dump site in the city but has now become a popular entertainment site (People's Daily, 2015). Sponge-like concepts were adopted in the park, such as collecting rainwater by using pervious concrete, purifying rainwater by building a rainwater garden, and watering plants with rainwater. The rainwater collecting system now collects and retains around $70 \%$ of the rainwater, which is sufficient for greenbelt sprinkling in the park. This alone saves RMB 1.5 million (USD 217,708) per year (People's Daily, 2015). Since the park was completed, around 600 households that had previously moved out from the rubbish dump site have moved back. The park won the Prize of China Habitat Environment in 2016, which is the highest prize for habitat environment construction in China. The success of the park has encouraged the municipal government to construct similar projects.

Bulkeley (2006) underlines that the dissemination of best practices (good examples) that can lead to policy change has become accepted wisdom in national policies and programmes. The Chinese government encouraged the development of sponge projects in pilot cities, which in turn play a crucial role in scaling up the sponge-like projects. These examples, as well as the financial and technical support (guidelines) from the central level, resulted in enthusiasm at the lower levels of government to take part in this effort.

\section{Governing by authority}

The SCP must respect the so-called Basic Laws, which provide the basis for action. These include the Construction Law (National People's Congress, 2011), the Urban-Rural Planning Law (National People's Congress, 2015) and the Environmental Assessment Law (National People's Congress, 2016). In addition to complying with general basic laws and compulsory standards, the SCP is required to integrate with several other ongoing projects, for example the Pilot Urban Tunnels project, which establishes tunnel networks in selected cities to hold pipelines for utilities such as water, electricity and telecommunications by 2020 (Ministry of Finance, \& Ministry of Housing \& Urban-Rural Development, 2014), and the Urban Black Odorous Water Clean Up project, which requires the removal of floating rubbish and illegal sewage discharges in provincial capital cities' rivers by 2017 (State Council, 2015a). The integration of these projects remains a great challenge in practice, which will be examined in the discussion section below.

The evaluation system is the central government's main mechanism to ensure the implementation of the SCP at the local level. The system comprises six dimensions (water ecology, water environment, water resources, water security, institutional capacity building and execution effectiveness), each of which has corresponding criteria and standards. These criteria and standards are either compulsory or recommended, depending on whether they can be 
met by current technology. Only compulsory criteria and standards are evaluated, in a threestage process. First, a pilot city applies a self-assessment based on the compulsory requirements. These assessment results need to be submitted to the provincial government. Second, the provincial government or its trusted third party reviews the results and draws up assessment reports, submitting them together with the city's self-assessment reports to the Ministry of Housing and Urban-Rural Development (MHURD). Third, the MHURD evaluates the submissions selectively. A city that fails the evaluation will receive a Notice of Criticism (depending on the performance) from the MHURD, and the provincial government leadership will also be held accountable. Although the evaluation policy does not prescribe specific consequences, a Notice of Criticism is usually considered a negative result. In the case of the SCP, the title of Sponge City might be revoked (depending on the performance) (SCP Symposium, 2016), and the local government officials may not be promoted, or may even be demoted, depending on their performance (Dai, 2014; Ye Qi et al., 2008). This consequence is strongly related to the (Communist) Party regulations, as almost all government leaders are Party members in China.

The Hubei provincial government recently published a notice to accelerate the progress of SCP within its jurisdiction (only Wuhan has initiated the SCP at the present stage.) The notice explicitly points out that the provincial government will closely supervise the SCP construction, and the government officials will be held accountable if the process is delayed or the leadership does not function well (Hubei Provincial Government, 2016). In this regard, the Wuhan municipal government must sign responsibility statements with the Hubei provincial government (SCP Symposium, 2016). Using this accountability system, the central government and the provincial government can ensure the implementation of the SCP at the local level.

Wuhan Municipality has allocated the responsibilities for SCP implementation to many different departments (Table 2). Consequently, the success of the SCP in Wuhan depends on cooperation between the various departments (see the discussion section below).

At the national level, the SCP programme complements several other water and land-use programmes. The importance of including SCP targets depends on the weight given to them in the central government's evaluation mechanism for civil servants at lower levels of government. The challenge of meeting the SCP targets at the local level may be further complicated by the fragmentation of competences among many local departments and the ensuing necessity of cooperation among them.

\section{Governing through provision}

The central government provides Application Guidelines (Ministry of Finance, Ministry of Housing \& Urban Development, \& Ministry of Water Resources, 2015) and Technical Guidelines for constructing the SCP (Ministry of Housing \& Urban-Rural Development, 2014).

The Application Guidelines provide selection procedures and the application format. The latter gives the candidate cities detailed instructions on how to investigate the city's topography, hydrogeological conditions, rainfall characteristics, flood features, the water resource situation, environmental, ecological conditions, and other relevant characteristics.

The Technical Guidelines work as a toolkit to provide standards and methods for the SCP from the planning and design stage to the construction and maintenance stage, and provide seven illustrative showcases. They aim to assist cities with SCP construction. The scope is 
Table 2. Allocation of Responsibilities for the Sponge City Programme in Wuhan.

\begin{tabular}{|c|c|}
\hline Departments & Responsibilities \\
\hline Water Affairs Bureau & $\begin{array}{l}\text { Daily routine of SCP management; improving the urban } \\
\text { waterlogging early warning and emergency response } \\
\text { system; drafting, formulating and promoting technical } \\
\text { standards and management regulations for water-re- } \\
\text { lated sponge projects }\end{array}$ \\
\hline Municipal Construction Commission & $\begin{array}{l}\text { Comprehensive coordination; reviewing construction } \\
\text { plans and supervising construction permits and } \\
\text { completion acceptance; formulating technical standards } \\
\text { and management regulations for urban road-related } \\
\text { sponge projects }\end{array}$ \\
\hline Municipal Development and Reform Commission & $\begin{array}{l}\text { Researching investment channels and mechanisms; } \\
\text { integrating the pilot SCP into the investment planning } \\
\text { of municipal infrastructure construction; coordinating } \\
\text { with other departments }\end{array}$ \\
\hline Municipal Planning Bureau & $\begin{array}{l}\text { Integrating the pilot SCP requirements into municipal } \\
\text { urban and rural planning; coordinating with other } \\
\text { departments }\end{array}$ \\
\hline Municipal Finance Bureau & $\begin{array}{l}\text { Coordinating with the Water Affairs Bureau on drafting the } \\
\text { SCP funding management methods and the sanctions } \\
\text { and incentives; developing a mid-to-long-term budget } \\
\text { system }\end{array}$ \\
\hline Municipal Gardening and Forestry Bureau & $\begin{array}{l}\text { Drafting and promoting technical standards for } \\
\text { landscaping and greening in the SCP pilot areas }\end{array}$ \\
\hline Municipal Department of Environmental Protection & $\begin{array}{l}\text { Monitoring and producing bulletins on the water quality } \\
\text { of the SCP pilot areas }\end{array}$ \\
\hline Municipal Meteorological Bureau & $\begin{array}{l}\text { Establishing the platform of storm monitoring and early } \\
\text { warning, collecting relevant information in pilot areas }\end{array}$ \\
\hline $\begin{array}{l}\text { Municipal City Management Committee and Housing } \\
\text { Management Bureau }\end{array}$ & $\begin{array}{l}\text { Implementing their management responsibilities for } \\
\text { public buildings, roads and residential districts in SCP } \\
\text { pilot areas }\end{array}$ \\
\hline Municipal Supervision Bureau & $\begin{array}{l}\text { Monitoring the performance of other departments } \\
\text { concerning the implementation of SCP regulations and } \\
\text { assigning responsibilities according to law }\end{array}$ \\
\hline Legal Office of Municipal Government & $\begin{array}{l}\text { Coordinating with the Water Resource Bureau to issue } \\
\text { SCP-related regulations }\end{array}$ \\
\hline Commission for Assessment of Municipal Government & $\begin{array}{l}\text { Managing process and performance evaluation in the SCP } \\
\text { pilot areas }\end{array}$ \\
\hline Pilot Projects District Government & $\begin{array}{l}\text { Implementing the SCP-related tasks and regulations in } \\
\text { their corresponding administrative areas }\end{array}$ \\
\hline Municipal Propaganda Department & Social propaganda and public opinions report \\
\hline
\end{tabular}

Source: Wuhan Municipality (2016). Implementation Plan on Pilots of Sponge City Programme in Wuhan City, https://www. wuhan.gov.cn/hbgovinfo/szfxxgkml/fggw/bgtwj/201604/t20160405_70399.html

broad, covering different sponge projects such as urban buildings, residential districts, roads, green spaces and water systems.

As the SCP calls for huge investments, the central government encourages the policy development of public-private partnerships (PPP). More than 70 PPP documents had been provided by the Ministry of Finance and the Development and Reform Committee by the end of 2015. Numerous favoured projects are introduced by these documents, but priority is given to newly approved municipal facilities and other urbanization projects (Thieriot \& Dominguez, 2015). The SCP can benefit from this.

In addition, the Ministry of Water Resources and the MHURD have organized many workshops to introduce and share the experience of SCP construction with cities nationwide.

At the city level, the Wuhan Water Affairs Bureau (2016) issued comprehensive Planning and Design Guidelines for the SCP. They provide SCP terminology, the planning and design 
parameters of the sponge projects, the evaluation standards of the different parameters, and the formulation of guidelines for general and specialized SCP planning and design.

To enhance cooperation and collaboration between the related departments, the municipal government established a Headquarters of Pilot Projects for the Construction of the Sponge City in the Water Affairs Bureau, which aims to provide a coordination platform to discuss the 'major policies and important decisions of the SCP' (Wuhan Municipality, 2016). The district governments where the SCP demonstration areas are located have also set up task forces to coordinate and implement the construction of the SCP in their jurisdictions. However, the platform and task forces do not play an important role in practice, which will be discussed in the discussion section.

The Chinese government assists private parties with subsidies and technical guidelines and expects private parties to come forward to partially fund SPC projects. PPP funding takes place, but it seems that private parties are reluctant to invest. Perhaps they are insufficiently involved in the decision-making process, which does not generate enthusiasm, or they find it simply too difficult to market the added value of a sponge city project.

\section{Governing through (co)funding}

The central government provides special funding for the selected pilot SCP cities as start-up capital over three years. The amounts of funding vary and depend on the administrative levels of the candidate cities, i.e. RMB 600 million (USD 88 million) for municipalities guided directly by the State Council, RMB 500 million (USD 73 million) for provincial capital cities, and RMB 400 million (USD 59 million) for the other cities (Ministry of Housing \& Urban-Rural Development, 2014).

The SCP projects require investment of hundreds of billions of RMB in the first batch. According to a survey, government investments (both central and local) account for only $33 \%$ in the seven pilot cities investigated; the rest is expected to be contributed through the PPP (PPP \& Sponge City Construction, 2016). Therefore, next to funding the SCP construction directly, the central government also encouraged financial institutions to set up credit support for the programme. The government requested the China Development Bank to give sponge projects credit support as a priority and offered incentives to commercial banks to provide mid- and long-term loans for SCP projects. A city that raises a certain percentage of funds through PPP for sponge projects will be awarded an additional $10 \%$ of the initial funding from the central government as a bonus (Ministry of Finance, \& Ministry of Housing \& Urban-Rural Development, 2014).

The municipal government of Wuhan plans to invest a total of RMB 16.3 billion (USD 2.4 billion) in 455 pilot sponge projects and the construction of monitoring platforms between 2015 and 2017 (Table 3). Besides the funding from the Central government, i.e. 500 million RMB (US\$ 73 million) per year, the municipal government is required to invest 400 million RMB (US\$ 59 million) per year, and the district governments where the SCP pilot schemes are located are required to invest a minimum of 100 million RMB (US\$ 15 million) per year (Wuhan Municipality, 2016). The plan is to raise the remaining funds through PPPs and longterm loans from banks to the governments of demonstration districts (Table 3).

To stimulate nongovernmental investments, the municipal government established a subsidy programme that rewards investors with $30 \%$ of the project investment if they initiated the sponge project using nongovernmental capital before 1 October 2015, and 15\% 
Table 3. Investment Channels of Sponge City Programme in Wuhan (2015-2017).

\begin{tabular}{ll}
\hline Channel of investment & \multicolumn{1}{c}{ Amount (millions) } \\
\hline Central government & RMB 500 (USD 73) $\times 3$ \\
Municipal government of Wuhan & RMB 400 (USD 59) $\times 3$ \\
Government of Qingshan District & RMB 100 (USD 15) $\times 3$ \\
Government of Sixin District & RMB $100($ (USD 15) $\times 3$ \\
PPPs and loans & RMB 13,000 (USD 1881) \\
Planned total investment & RMB 16,300 (USD 2367) \\
\hline
\end{tabular}

Source: Wuhan Water Affairs Bureau (2016). Guidlines of Sponge City Plan and Design, https://www.whwater.gov.cn/water/u/ cms/www/201507/08110535klk6.pdf

after this date. The municipal government encouraged the PPP model and promoted the participation of social capital by various means, for example by taking advantage of the national supporting policies of the SCP to obtain long-term loans from banks and by establishing business conglomerates consisting of construction companies, manufacturers and financial institutions. In addition, the Municipal Planning Bureau and the Municipal Gardening and Forestry Bureau were required to give financial priority to the SCP when reviewing and approving city planning.

\section{Discussion based the four modes of governance}

Looking at the different governance modes used at the central and local levels, we identified the strengths and weaknesses of the SCP at the present stage (Table 4).

We can see strong political steering of SCP at the central level. From the beginning, governing through authority has been used by means of basic laws, compulsory engineering standards, the requirement of responsibility statements, and compliance mechanisms. This is accompanied by provisions such as application and technical guidelines, support for PPPs, and (co)funding instruments such as direct funding. Among these factors, some can support successful implementation of SCP. At the same time, some must be further explored to ensure the success of SCP.

\section{Political advantage of being an SCP pilot city}

The central government has funded two batches of 30 SCP pilots since 2015. Pilot cities provide platforms to test the value and reveal the deficiencies of SCP before scaling up the programme nation-wide. Therefore, this can be regarded as one of the best practices of the Chinese SCP. Local governments in China are highly interested in applying to become pilots. In addition to the practical need for sustainable rainwater management, their other major factors are the large amount of funding from central government, the economic benefits

Table 4. Main strengths and weaknesses of the SCP in China.

\begin{tabular}{ll}
\hline Strengths & \multicolumn{1}{c}{ Weaknesses } \\
\hline - Starting with pilot cities & - Difficulties with public-private partnerships \\
- Providing technical guidelines & - Time pressure \\
- Providing funding opportunities. & - Lack of experience \\
& - Weak implementation of existing regulations \\
& - Lack of efficient cooperation \\
& - Lack of public participation.
\end{tabular}


that the SCP could bring, and showing an active response to a call from a higher level of government (which is important in a one-party state).

\section{Top-down supervision system}

The central government ensures the implementation of the SCP by evaluating the personnel in lower governments. Provinces have mainly a supervisory role but also their own responsibility to make the SCP successful. At the local level of Wuhan City, national requirements are implemented within the formal authoritative governance mode of an SCP management system. The scope for autonomous development is narrow, and the focus is on the implementation of national policies to comply with the requirements set at the national level, to avoid punishment and also to achieve a more climate-resilient city. The deliberate choice of a top-down mechanism with clear and binding rules and strict deadlines makes compliance and enforcement easy and effective.

\section{Funding}

The investment by the central government in the first two batches of SCP has amounted to RMB 40 billion (USD 6 billion) (Feng, 2016). However, it is far from enough. The SCP requires RMB 100-150 million (USD 15-22 million) in investment for each square kilometre under development (Xu, 2015), which poses great challenges for both central and local governments. The central government has been keen to promote PPPs because they allow governments to transfer risks to the private sector at a fixed price, to accelerate project delivery, to reduce total project costs, and to improve cost certainty for the public sector (Global Credit Research, 2017). However, the PPP market in China is still in an emerging stage.

Research indicates that the expected effects of expanding PPPs nationwide are difficult to achieve in practice for several reasons. First, the existing policies conflict with each other in certain areas. The PPP policies were drafted mainly by the Ministry of Finance and the National Development and Reform Commission at the central level. Both ministries have tried to dominate the decision-making authority, so their respective interests were to a large extent reflected in their own policies. As a result, it is difficult for local governments to manage policy conflicts (Yu, 2016).

Second, there is distrust between the governments and private investors. Local governments are reluctant to transfer their most promising projects to private investors. Many officials are suspicious of private firms. For example, the Beijing municipality recently signed a PPP agreement for a new highway, and picked China Railway Construction Corporation, a vast state-owned enterprise, as its partner. The official in charge suggested that private companies had neither the ability nor the necessary capital (The Economist, 2016). While using the English-language abbreviation PPP, China defines the non-government partner as 'social capital' instead of 'private capital', which opens the door for state-run firms since they usually accept lower returns and get cheaper financing than the private firms (Bloomberg News, 2017).

The PPP partner in Wuhan is also a state-owned company. At the time of writing, Wuhan has raised around RMB 1.3 billion (USD 189 million) in 'social capital' through a state-owned company (Wuhan Urban and Rural Construction Commission, 2017a), which is only around $10 \%$ of the planned investment by PPP and loans. Private firms are often wary of participating 
in such partnerships because they would be vulnerable to unfair treatment from local governments and likely to receive limited legal protection from local courts in the event of a dispute (Lockett, 2017).

Third, given the significant and long-term commitments involved for SCP contractors, it can be risky for private investors to pursue a PPP programme. For many sponge projects, it is not clear to private investors how they can obtain returns on their investment. Unlike toll roads or power stations, green parks are usually not easily converted into profits. The 'private' component of the PPP is typically state-run at the current stage (Lockett, 2017). In the case of Wuhan, 84 projects in Qingshan District were handed over to a state-owned company for a duration of 10 years (2 years' construction and 8 years' operation). The package covers 11 city roads, 68 public facilities in residential areas, three urban drainage trenches and one green park (Wuhan Urban and Rural Construction Commission, 2017b). However, it is unclear how the company will make a profit, since the contract has only recently been signed.

In fact, the investment enthusiasm of private investors in sponge projects seems to be waning. Statistics show that over the first eight months of 2016, private-sector investment rose by just $2.1 \%$ from the same period a year earlier, virtually the lowest rise since records began in 2005 (The Economist, 2016). Therefore, the current funding mechanism may become one of the main obstacles to scaling up the SCP to a nationwide roll-out. The central government has tried to improve the PPP mechanism by listing it in the legislation tasks of 2017. However, considering that there are only three years available for implementing the first batch of SCP and the long process of legislation in general, the expected legislation might only have limited effects on the first batch of SCPs.

\section{Time pressure}

The SCP has a clear timetable for implementation, which is a good practice in general, but could also constrain the process or the effectiveness of the project if the plan is unrealistic. The first batch of pilot cities were given only three months to design their sponge projects. Field research in Wuhan shows that time is a pressing factor affecting the process of SCP construction (SCP Symposium, 2016). The engineering designers who contracted with the municipal government worked overtime to keep up with the tight time schedules, often sleeping in hotels near work to save time. The period for the review of drawings undertaken by a third party was also often compressed, sometimes with only a few hours to review the progress made. However, according to the MHURD, $59.8 \%$ of the planned projects nationwide started construction by the middle of 2016, and $61 \%$ (276 of 455) started in Wuhan by the end of 2016 (Zhao, 2016). It seems that the deadline can be met by the end of 2017. But the greatest concern is that, as a landscape architect said, 'The expected achievements might not be achieved because the design is often too simple and the sponge concepts are often applied mechanically [due to a lack of time]' (Zhao, 2016).

\section{Indispensable tools and skills}

Technical guidelines from the central government could serve as a good practice too, since the guidelines outline useful technical approaches and methods that could help the pilot cities design and implement sponge projects. However, several obstacles and challenges have also been demonstrated, as the SPC is in practice far more complex than expected. For 
example, SCP is marked by the complexity of its design and construction, since most projects are interconnected with many others, such as urban water system planning, urban green space engineering, and drainage system planning. The traditional institutions are usually not familiar with or capable of managing this new situation. This also brings great challenges for practitioners. Although the design idea is sponge-based, construction errors often occur because the practitioners are not specially trained in sponge design and are still used to traditional working methods. For example, according to the sponge-based design idea, when paving roads in some cases, the voids in between the paver bricks should be filled by polymeric sand so as to be water-permeable, but practitioners often act on their own, using the traditional cement, which is very different from the original design (SCP Symposium, 2016). However, developing tailor-made solutions also takes time.

\section{Weak implementation of existing regulations and programmes}

Another barrier to accelerating the SCP is that current planning policies and regulations are often poorly implemented. According to a water supply and drainage expert,

A previous national task to formulate the Urban Drainage and Flood Control Construction Planning within a year in 2013 has failed in many cities, while another five-year-period task of reconstructing the drainage network (2013-2017) still remains unfinished to a large extent (Che, 2016).

Implementation of existing regulations is also weak in Wuhan. For example, according to an expert in flooding survey and control, the existing drainage facilities in the city have not met even half of the intended standards (Xinhua Caijin, 2015). The city's systems can cope with the expected annual floods, which is far from being able to cope with 50-year floods as required by central government.

\section{Integrating SCP in other policies and programmes}

Integrating the SCP with the Pilot Urban Tunnel Programme and the Urban Black Odorous Water Clean-Up Programme is another arduous task. The weak implementation of drainage regulations poses challenges for the Pilot Urban Tunnel Programme, which is experiencing great difficulties in meeting its deadlines. Integrating it with the SCP without a carefully coordinated plan will only exacerbate the difficulties. A total of 218 of 295 cities nationwide (covering 1897 rivers in total) fall within the Urban Black Odorous Water Clean-Up Programme. This requires that all pollution sources be investigated and effectively controlled, an enormous challenge considering that water scarcity is increasing. Diffuse-source pollution is becoming worse and increases the risk of soil pollution since it spreads over very wide areas and lodges in the soil, further threatening food quality. This makes the clean-up programme more complex, even apart from integrating it with the SCP in the short term.

There are four rivers and one lake on the list in Wuhan. The work of cleaning up these five black odorous water bodies is mainly the responsibility of the Water Affairs Bureau and the Department of Environmental Protection, while the SCP design is the responsibility of the Municipal Construction Commission. However, cooperation between different departments is difficult (SCP Symposium, 2016). Besides a long-standing problem of 'fragmentation' in the Chinese bureaucratic system (Dai, 2014) and the Urban Black Odorous Water Clean-Up Programme, the SCP and the Pilot Urban Tunnel Programme are new and full of complexities 
and uncertainties. However, the development of integrated management takes time and careful planning from the early strategic drafting stages, and these seem to be currently missing.

\section{Lack of public participation}

It is also important to recognize that 'public participation' is not a compulsory component of the SCP policies. This is not surprising considering that, in general, legislative provisions for public participation in China are still confined to abstract principles (Li, 2013). The governing socialist ideology and traditional Chinese culture give priority first to national interests, then to collective interests, and lastly to individual interests. The central government has championed the ideas of 'collectivism' and 'national interests' in its ideological and moral education programmes for years. These principles have largely infiltrated China's planning ideology (Tang, Wong, \& Lau, 2008). Although non-government stakeholders have gained more attention during the past decade, they have yet to play a significant role in policy-making processes, and there are no institutionalized channels allowing them to influence decision making ( $\mathrm{Li}, 2013)$.

In the case of the SCP in Wuhan, problems have occurred, e.g. residents who were not happy with construction waste being dumped in their neighbourhoods without notice. However, large-scale protests against sponge projects have not occurred or at least were not reported. Nonetheless, it would be more sustainable to involve non-government stakeholders, especially residents, in the process of sponge city design and construction (Glucker, Driessen, Kolhoff, \& Runhaar, 2013), since cities are created to serve the interests and needs of residents; and they often best know their actual needs. In addition, stakeholder engagement can build trust and ownership, and raise awareness of current and future risks (OECD, 2016).

\section{General guidelines versus local needs}

Innovative actions require technical, material and financial support. Both the central government and the Wuhan municipal government have provided the city planners with technical guidelines. These are helpful for the managers and builders to a certain extent. However, since geographical conditions have specific relevance to urban water issues, even within the same city the old districts and the new ones require different solutions, and given the diversity of the sponge projects, those guidelines are still far from providing clarity. More tailored technical guidelines should be developed, according to local conditions.

Some requirements of the guidelines cannot even be implemented. For example, although all the guidelines at both the central and Wuhan levels emphasize the rainwater-purification function of the sponge projects, currently available construction materials are not able to meet this requirement (Wang, 2016).

In the guidelines at both levels, although much attention has been paid to the projects' construction, operation and maintenance issues have been largely ignored. According to the SCP director of Wuhan, managing the projects during and after construction would be a big problem for the city. A survey has shown that, among the finished projects of the first batch of SCP nationwide, profitable projects such as pipelines are usually easier to hand over to operators, whereas public projects such as parks and grasslands generally lack maintenance after completion (Sponge City, 2016). 
In its guidelines Wuhan promotes the cooperation aspect of the SCP among different departments; however, we would rather call such cooperation a handover, in which, for example, the projects are designed by the Municipal Construction Commission and then transferred to the Municipal Development and Reform Commission to be checked. The latter commission does not participate from the beginning in the design process. In other words, the established platform and the task forces have not played their due role in the management of sponge projects.

\section{High expectations and window dressing}

In many cases sponge projects are seen as a panacea to address problems of urban flooding or waterlogging (Wu, Zhao, \& Li, 2015). However, sponge projects alone cannot manage the risks associated with urban flooding, especially in some old residential areas where drainage facilities have not been repaired. Premier Li Keqiang, in the annual government work report in 2017, emphasized that "when taking solid steps to pursue a new type of urbanization, coordinated urban development should be promoted above and below the ground" (Li, 2017). In the past, too many 'image projects' ('structures or complexes with no practical use other than to raise a town's profile' - Abrams, 2010) were constructed aboveground, but facilities belowground, like the drainage network, were disappointing. 'About one-fifth of China's 660 cities and more than 20,000 towns have too many Image Projects', according to the former vice-minister of housing and urban-rural development $(\mathrm{Hu}, 2010)$.

At times, reviewers of SCP applications have noticed that'sponge city' was adopted as an ideological concept, but few people knew exactly what it meant from a practical perspective (O'Meara, 2015). Local governments should ensure that they do not make the mistake of turning the SCP into image projects. This, however, remains a challenge under the current governmental evaluation system, in which the promotion of government officials is usually based on their performance, which may be enhanced by large engineering projects. This demands structural reform.

\section{Conclusion}

Although Chinese cities are suffering from floods more often than previously, this has also created an opportunity for innovative urban design. The State initiated SCP as a pilot programme to relieve flood inundations. This article analyzes the SCP through a governance framework comprising four modes: governing by example, governing through regulation, governing through provision and governing through (co)funding.

We observed that the government in China plays a significant role and that civil society is merely the recipient. This is not surprising, however, considering that big projects in the country are generally the result of a top-down approach. This approach, accompanied by a well-placed evaluation system and the provision of technical guidelines and direct funding, is intended to make the implementation efficient. While this may not be suitable for all countries, starting with pilot cities is a good practice because it provides valuable experience for scaling up the programme.

Besides the strengths, we also found some weaknesses that could cause risks for the SCP. The unsatisfactory application of PPP and the tight timetables are the main obstacles. Although PPP could expand the channel of financial investments, the current PPP mechanism 
is not mature enough to attract private investments and ensure their rights. The approach of the SCP is new to China. Understanding and embracing new ideas, improving technical know-how, creating a skilled workforce, improving the PPP scheme, learning and further developing the concept based on best practices derived from the pilot projects, takes time. Yet time is hardly available. The pressing timetables can therefore constrain the effectiveness of the SCP.

We suggest that the governments slow the pace and remedy the deficiencies by, for example, enforcing existing regulations and standards to provide solid foundations for the SCP; building institutional capacity so that departments can efficiently cooperate with each other; empowering a broader range of actors to bring different resources to the programme; and reconciling diverse sectional interests to develop a more efficient financial support mechanism. All these are fundamental factors for establishing a long-term effective mechanism for the SCP.

\section{Acknowledgement}

We would like to thank Jesse Reynolds for his valuable suggestions for improvement.

\section{Disclosure statement}

No potential conflict of interest was reported by the authors.

\section{Funding}

This work was supported by the Koninklijke Nederlandse Akademie Van Wetenschappen (Royal Netherlands Academy of Arts and Sciences) [grant number 530-6CDI01] of the China Exchange Programme; Future Deltas of Utrecht University, under WBS no. WA.147101.2.707, and InstitutionsSeed Money 4th round.

\section{References}

Abrams, S. (2010, June 23). Image projects illustrate China's urban planning shortcomings. Retrieved July 7, 2017, from China Hear Say: https://www.chinahearsay.com/image-projects-illustrate-chinasurban-planning-shortcomings/

Arch Daily. (2013, November 10). Qunli stormwater wetland park / turenscape. Retrieved July 7, 2017, from Arch daily: https://www.archdaily.com/446025/qunli-stormwater-wetland-park-turenscape

Asian Development Bank. (2013). Guidebook: Increasing climate change resilience of urban water infrastructure. Mandaluyong: Asian Development Bank.

Bloomberg News. (2017, February 27). Bloomberg. Retrieved July 3, 2017, from In China, Public-Private Partnerships Are Really Public-Public https://www.bloomberg.com/news/articles/2017-02-27/inchina-public-private-partnerships-are-really-public-public

Bulkeley, H. (2006). Urban Sustainability: Learning from best practice? Environment and Planning A, 38, 1029-1044. 10.1068/a37300

Bulkeley, H., \& Broto, V. (2012). Government by experiment? Global cities and the governing of climate change. Transactions of the Institute of British Geographers, 38, 361-375, doi:10.1111/j.14755661.2012.00535.x

CCICED. (2016). China's ecological civilization and the world. CCICED. Retrieved from https://www.cciced. net/cciceden/POLICY/rr/prr/2016/201612/P020161214521507778827.pdf

Che, W. (2016, April 25). The key technology and difficulty of sponge city construction. Retrieved July 7 , 2017, from https://www.archcy.com/point/benzdj/1217cc289876a436 
China Daily. (2017, March 22). Xi leads ecological civilization. Retrieved July 7, 2017, from China Daily https://www.chinadaily.com.cn/china/2017-03/22/content_28634915.htm

China Urban Centre. (2016, July 9). Why floods occur frequently in Wuhan. Retrieved July 7, 2017, from https://www.360doc.com/content/16/0709/19/30072915_574304484.shtml

Dai, L. (2014). A new perspective on water governance in China: Captain of the river. Water International, 40, 87-99. doi: $125.235 .8 .196: 8080$

Dai, L. (2015). Identifying and understanding the main challenges for sustainable water resource management in China. Journal of Water Law, 5, 249-264.

Ding, Y., Ren, G., Shi, G., Gong, P., Zheng, X., Zhai, P., \& Dai, X. (2007). China's national assessment report on climate change (I): Climate change in China and the future trend. Advances in Climate Change Research, 3(12), 1-5.

Driessen, P., Dieperink, C., Laerhoven, F., Runhaar, H., \& Vermeulen, W. (2012). Towards a conceptual framework for the study of shifts in modes of environmental governance - experiences from the Netherlands. Environmental Policy and Governance, 22, 143-160. doi:10.1002/eet.1580

Duan, W., He, B., Nover, D., Fan, J., Yang, G., Chen, W., \& Meng, C. (2016). Floods and associated socioeconomic damages in China over the last century. Natural Hazards, 82, 401-413. doi:10.1007/ s11069-016-2207-2

The Economist. (2016, September 17). A sponge wrung dry. Retrieved July 17, 2017, from https://www. economist.com/news/finance-and-economics/21707192-chinas-private-investors-keep-theirhands-their-pockets-sponge-wrung-dry

Feng, Y. (2016, June 8). 40 billion for two batches of sponge cities within three years. Retrieved July 7, 2017, from www.cnenergy.org: https://www.cnenergy.org/hb/jzyth/201606/t20160608_315492.html

Global Credit Research. (2017, March 15). Moody's investors service. Retrieved July 3, 2017, from Moody's: Chinese government support for public-private partnerships boosts growth prospects: https://www. moodys.com/research/Moodys-Chinese-government-support-for-public-private-partnershipsboosts-growth-PR_363505

Glucker, A., Driessen, P., Kolhoff, A., \& Runhaar, H. (2013). Public participation in environmental impact assessment: Why, who and how? Environmental Impact Assessment Review, 43, 104-111, doi:10.1016/j. eiar.2013.06.003

Guha-Sapir, D., Hoyois, P., \& Below, R. (2015). Annual disaster statistical review 2014 - The numbers and trends. Brussels: Centre for Research on the Epidemiology of Disasters (CRED).

Hu, Y. (2010, June 23). 'Landmarks'smear image. Retrieved July 7, 2017, from China Daily: https://www. chinadaily.com.cn/china/2010-06/23/content_10005886.htm

Huang, S., \& Xu, G. (2006). Influence of urbanization development on urban flood disasters and mitigation countermeasure. Journal of Anhui University Natural Science Edition, 30, 91-94.

Hubei Provincial Government. (2016). Notice of speeding up the construction of comprehensive tunnel of utility and sponge city. Retrieved July 7, 2017, from https://chhd.com.cn/content/us/220505-7101cm00001.html

Kern, K., \& Alber, G. (2009). Governing climate change in cities: Modes of urban climate governance in multi-level systems. In Proceedings of the international conference on competitive cities and climate change (pp. 171-196). Milan: OECD.

Kobayashi, Y., \& Porter, J. (2012). Flood risk management in the People's Republic of China, learning to live with flood risk. Mandaluyong: Asian Development Bank. Retrieved from https://www.adb.org/sites/ default/files/publication/29717/flood-risk-management-prc.pdf

Li, B. (2013). Governing urban climate change adaptation in China. Environment and Urbanization, 25, 413-427. doi:10.1177/0956247813490907

Li, K. (2017). Report on the work of the government. Beijing: Fifth Session of the 12th National People's Congress.

Lockett, H. (2017, February 20). Financial times. Retrieved July 3, 2017, from China's state firms lead on public-private infrastructure projects: Fitch https://www.ft.com/content/14a44049-22bf-3062b5b2-79ebe77b0d95?mhq5j=e1

Mees, H. (2014). Responsible climate change adaptation, exploring, analysing and evaluating public and private responsibilities for urban adaptation to climate change. Utrecht: Utrecht University. 
Miller, M., \& Douglass, M. (2015). Governing flooding in Asia's urban transition. Pacific Affairs An International Review of Asia and the Pacific, 88, 499-515.

Ministry of Civil Affairs. (2016). Situation of natural disasters in the first half of 2016 . Retrieved July 7, 2017, from Ministry of Civil Affairs: https://www.mca.gov.cn/article/zwgk/mzyw/201607/20160700001126. shtml

Ministry of Finance, Ministry of Housing and Urban Development, \& Ministry of Water Resources. (2015). 2015 guidelines of sponge city programme application. Retrieved July 7, 2017, from https://jjs.mof. gov.cn/zhengwuxinxi/tongzhigonggao/201501/t20150121_1182677.html

Ministry of Finance, \& Ministry of Housing and Urban-Rural Development. (2014). The notice of the development of central financial support on sponge city programme. Retrieved July 7, 2017, from https://jjs.mof.gov.cn/zhengwuxinxi/tongzhigonggao/201501/t20150115_1180280.html

Ministry of Housing and Urban-Rural Development. (2014). Technical guidelines on sponge city contruction-low impact development of storm sewer system (Trial). Retrieved July 7, 2017, from https:// www.mohurd.gov.cn/zcfg/jsbwj_0/jsbwjcsjs/201411/t20141102_219465.htm

National Development and Reform Commission. (2015). China's policies and actions on climate change. Beijing: National Development and Reform Commission.

National People's Congress. (2011). Construction law. Retrieved August 21, 2017, from https://en.pkulaw. $\mathrm{cn} /$ display.aspx?cgid=18974\&lib=law

National People's Congress. (2015). Urban-rural planning law. Retrieved August 21, 2017, from https:// en.pkulaw.cn/display.aspx?cgid=252605\&lib=law

National People's Congress. (2016). Enviornmental assessment law. Retrieved August 21, 2017, from https://en.pkulaw.cn/display.aspx?cgid=274320\&lib=law

National New Urbanization Plan (2014-2020). (2014, March 16). https://www.gov.cn/ zhengce/2014-03/16/content_2640075.htm Retrieved July 7, 2017, from Central Government https://www.gov.cn/zhengce/2014-03/16/content_2640075.htm

O'Meara, S. (2015, November 23). Why China wants to build something called 'sponge cities'. Retrieved April 18, 2017, from Citylab: https://www.citylab.com/design/2015/11/why-china-wants-to-buildsponge-cities/417114/

OECD. (2016). Water governance in cities. Paris: OECD Publishing. doi: 10.1787/9789264251090-en

18th Party Congress Report. (2012, November 8). 18th party congress report: Promoting ecological civilization construction. Retrieved July 7, 2017, from The Central People's Government of the People's Republic of China https://www.gov.cn/Idhd/2012-11/08/content_2260053

People's Daily. (2015, December 21). Wuhan: Garbage mountain transforms into garden expo park. Retrieved March 30, 2017, from Ecological civilization of China https://www.cecrpa.org.cn/stjj/7870. $\mathrm{htm}$

Piao, S., Ciais, P., Huang, Y., Shen, z., Peng, S., Li, J., . . Zhou, J. (2010). The impacts of climate change on water resources and agriculture in China. Nature, 467, 43-51. doi: 10.1038/nature09364

PPP and Sponge City Construction. (2016, December 20). Retrieved June 28, 2017, from Sina Financial https://cj.sina.com.cn/article/detail/5859352353/128727?column=china\&ch=9

SCP Symposium. (2016, May 16-17). Paper presented at the Symposium of Policy and Regulation Discussion on Wuhan Sponge City Programme. Wuhan, Hubei, China.

Shepard, W. (2016, July 28). Can 'sponge cities' solve China's urban flooding problem? Retrieved July 7, 2017, from citiscope https://citiscope.org/story/2016/can-sponge-cities-solve-chinas-urbanflooding-problem

Sponge City. (2016). The first batch of sponge city faces annual evaluation. Retrieved July 7, 2017, from Sponge City Website: https://www.calid.cn/2016/08/14602

State Council. (2015). The Action plan for prevention and treatment ofwater pollution. Retrieved July 7, 2017, from State Concil https://www.gov.cn/zhengce/content/2015-04/16/content_9613.htm

State Council. (2015, October 16). Guiding opinions of the general office of the state council on advancing the construction of sponge cities. Retrieved July 7, 2017, from Central Government https://www.djy. gov.cn/xxgk/zyxxzz/201510/t20151016_46623.html

Sudworth, J. (2015, March 11). China eyes fundamental shift in energy policy. Retrieved March 28, 2017, from BBC https://www.bbc.com/news/business-31689722 
Tang, B.-S., Wong, S.-W., \& Lau, M.-H. (2008). Social impact assessment and public participation in China: A case study of land requisition in Guangzhou. Environmental Impact Assessment Review, 28, 57-72. 10.1016/j.eiar.2007.03.004

Thieriot, H., \& Dominguez, C. (2015). Public-private partnerships in China: On 2014 as a landmark year, with past and future challenges (Discussion Paper). Retrieved July 17, 2017, from https://www.iisd. $\mathrm{org} / \mathrm{sites} /$ default/files/publications/public-private-partnerships-china.pdf

Turenscape Landscape Architecture. (2015, March 24). Yanweizhou Park in Jinhua City. Retrieved July 17, 2017, from Lawn Care Professionals: https://www.landezine.com/index.php/2015/03/a-resilientlandscape-yanweizhou-park-in-jinhua-city-by-turenscape/

Wang, F. (2016, July 6). Finanicial distress in sponge city programme. Retrieved July 17, 2017, from 21 st Century Economic Report: https://epaper.21jingji.com/html/2016-07/06/content_43015.htm

Wernick, A. (2016, September 25). The US and China have now officially ratified the Paris climate agreement. Retrieved March 28, 2017, from PRI https://www.pri.org/stories/2016-09-25/us-and-china-have-nowofficially-ratified-paris-climate-agreement

Wu, C., Zhao, Y., \& Li, J. (2015). Consideration and discussion about sponge city. South Achitecture, 4, 104-107.

Wuhan Municipality. (2016). Implementation plan on pilots of sponge city programme in Wuhan city. Retrieved July 17, 2017, from https://www.wuhan.gov.cn/hbgovinfo/szfxxgkml/fggw/bgtwj/201604/ t20160405_70399.html

Wuhan Urban and Rural Construction Commission. (2017a, January 4). The first PPP programme was born. Retrieved July 17, 2017, from Wuhan Urban and Rural Construction Commission https://hygl. whjs.gov.cn/content/2017-01/04/content_405051.htm

Wuhan Urban and Rural Construction Commission. (2017b, January 4). Transfomation of Wuhan iron and steel construct: "Urban construction service providers". Retrieved April 18, 2017, from Wuhan Urban and Rural Construction Commissio https://hygl.whjs.gov.cn/content/2017-01/04/content_405051.htm

Wuhan Water Affairs Bureau. (2016). Guidlines of sponge city plan and design. Retrieved July 17, 2017, from https://www.whwater.gov.cn/water/u/cms/www/201507/08110535klk6.pdf

Xinhua Caijin. $(2015,83)$. Wuhan: The mode of " $2+n$ " pilot construction of sponge city. Retrieved July 17 , 2017, from Xianhua Caijin: https://sc.xfafinance.com/html/Dont_Miss/2015/67469.shtml

Xu, W. (2015, July 1). 'Sponge City' program set to soak up urban floodwater. Retrieved July 17, 2017, from China Daily https://www.chinadaily.com.cn/2015-07/01/content_21148560_2.htm

Ye Qi, Y., Li Ma, L., Huanbo Zhang, H., \& Huimin Li, H. (2008). Translating a global issue into local priority. The Journal of Environment \& Development, 17, 379-400. Retrieved from http://journals.sagepub. com/doi/abs/10.1177/107049650832612310.1177/1070496508326123

Yin, J., Ye, M., Yin, Z., \& Xu, S. (2015). A review of advances in urban flood risk analysis over China. Stochastic Environmental Research and Risk Assessment, 29, 1063-1070. 10.1007/s00477-014-0939-7

$\mathrm{Yu}, \mathrm{W}$. (2016). The issue of legislation in ppp regulation discussion from the perspective of legal policy. Contemporary Legal Science, 70. Retrieved from https://www.pkulaw.cn/fulltext_form. aspx?Db=qikan\&gid $=1510162444$

Zhao, Y. (2016, August 9). First annual review of spong city: Time is tight but tasks are tough. Retrieved April 13, 2017, from Infzm https://www.infzm.com/content/118747 